\title{
PENGEMBANGAN KUMALASARI (BUKU PEDOMAN BELAJAR SISWA MANDIRI) BAGI SISWA KELAS V SD
}

\author{
Arik Umi Pujiastuti ${ }^{1}$, Dewantari Dharma Pramudya Wardhani ${ }^{2}$ \\ ${ }^{1}$ Universitas PGRI Ronggolawe \\ Email: arik.umi86@gmail.com \\ ${ }^{2}$ Yayasan Pendidikan Muhammadiyah Palang \\ Email: dewantaridharma98@gmail.com
}

\begin{abstract}
Abstrak
Penelitian ini bertujuan mengembangkan produk berupa buku pedoman belajar siswa mandiri. Adanya pengembangan yang dilakukan untuk memberikan alternatif solusi pembelajaran saat pandemi Covid 19. Jenis penelitian adalah pengembangan dengan menggunakan model Borg an Gall. Prosedur yang dilakukan adalah 1) Potensi dan Masalah, 2) Pengumpulan Data, 3) Desain Produk, 4) Validasi Desain, 5) Revisi Desain. Instrumen yang digunakan adalah, lembar angket, lembar wawancara, lembar validasi, dan lembar catatan proses pengembangan. Adapun hasil dari pengumpulan data bahwa, hanya $15 \%$ orang tua yang mendampingi putraputrinya belajar, $100 \%$ orang tua merasa pembelajaran tidak efektif, $85 \%$ petunjuk yang dibeikan guru dalam mengerjakan tugas tidak. Hasil angket siswa menunjukkan, sebanyak $85 \%$ mereka jenuh dengan pembelajaran dan $85 \%$ menginginkan petunjuk yang jelas dalam pengerjaan tugas. Berdasarkan hal tersebut maka dibuatlah desain produk dan dilakukan penilaian dengan validasi oleh 3 ahli, materi, bahasa, desain. Hasil validasi pertama masing-masing ahli materi, bahasa, dan desain didapatkan rata-rata dan persentase, 2.6, 2, 2.6, $52 \%, 20 \%$, $52 \%$. Berdasarkan masukan yang diberikan maka ada perbaikan produk sehingga hasil validasi mengalami peningkatan rata-rata dan persentase dari ketiga validator yaitu, ahli materi 4.6 persentase $96 \%$, ahli bahasa dan persentase $80 \%$, ahli desain 4.6 dengan ersentase $92 \%$. Berdasarkan hasil yang didapatkan maka produk yang dikembangkan layak untuk digunakan.
\end{abstract}

Kata kunci: kumalasari, siswa kelas V SD

\begin{abstract}
The study aims at developing a product of a self-contained student study manual. Development has been made to provide alternative learning solutions at the covid pandemic 19. The kind of research is expanding using the borg and gall model. The procedure done is 1) potential and problem, 2) data collection, 3) product design, 4) design validation, 5) design revision. The instruments used are snap sheets, interview sheets, validation sheets, and development process log sheets. As for the results of the data collection that only $15 \%$ of parents accompanying their sons and daughters learn, $100 \%$ of parents feel that learning is ineffective, 85 percent of the instructions a teacher provides in non-performing duties. Student estimates show, as many as $85 \%$ are saturated with learning and $85 \%$ want clear instructions in the job's performance. Based on that, it is created the design of the product and done a validation assessment by 3 experts, materials, languages, design. The results of the first validation of each expert in matter, language, and design are acquired average and percentage, 2.6, 2, 2.6, 52\%, 20\%, 52\%. Based on the input provided, the results of the product were improved, and the percentage of the validator averaged 4.6 percentage of $96 \%$, linguist and $80 \%$ percentage, designer 4.6 with $92 \%$ percentage. Based on the results obtained, the product developed is worth using.
\end{abstract}

Keywords: KUMALASARI, Elementary School V Graders 


\section{Pendahuluan}

Belajar memang tidak asing bagi semua orang, sebuah hal lumrah jika seseorang mengatakan bahwa belajar adalah sebagian dari kebutuhan manusia yang harus dipenuhi.

Menurut Hermawan et al., (2019) belajar merupakan sebuah proses seseorang untuk memperoleh pengetahuan dan pengalaman, dimana menjadi hal yang penting untuk setiap individu bertujuan mengetahui hal yang belum diketahui sebelumnya. Sedangkan, menurut Murfiah (dalam Rahayu, 2019) bahwa dalam kehidupan ini belajar adalah suatu kebutuhan yang mendasar, tanpa belajar kehidupan ini tidak akan berarti.

Berdasarkan pendapat tersebut dapat diartikan jika belajar adalah sebuah proses meningkatkan daya pikir serta pola perilaku manusia. Pada dasarnya manusia pasti membutuhkan proses belajar sejak dini, belajar akan berjalan efektif jika dilakukan secara konvensional.

Pada tanggal 30 Januari 2020 WHO telah menetapkan sebagai darurat kesehatan masyarakat yang merasahkan dunia. Hampir 26 negara diseluruh dunia terjangkit oleh wabah ini, yang sekarang telah kita ketahui dengan Covid-19 atau Coronavirus dimana virus ini memiliki gejala yang hampir sama dengan flue pada umumnya seperti, suhu badan tinggi, pilek, batuk, sesak napas. Namun, yang membedakan tentang virus ini dengan flue pada umumnya adalah penularannya yang tidak diketahui, dengan proses penyebaran melalui sentuhan pada benda mati, atau manusia lainnya (Mehta et al., 2020). Di Indonesia awal terkonfirmasinya virus ini pada awal bulan Maret 2020, tepatnya tanggal 2 Maret 2020 dimana dilaporkan 2 orang yang terjangkit virus ini. Lalu pada tanggal 16 Maret 2020 terkonfirmasi lagi sebanyaknya 10 orang terkonfirmasi positif Coronavirus, menurut Yurianto, dkk (dalam Dewi, 2020).

Menurut Xu et al., (2020) dalam artikelnya yang berjudul "Pathological Findings of COVID-19 Associated with Acute Respiratory Distress Syndrome" sejak akhir Desember, 2019, dalam sebuah novel coronavirus disease (COVID-19, yang sebelumnya dikenal sebagai 2019-nCoV) yang ditemukan di Wuhan, China. Yang kemudian menginfeksi hampir 26 negara diseluruh dunia. Pada umumnya COVID-19 adalah sebuah penyakit yang dapat disembuhkan, tapi juga bisa membunuh.

Akibatnya kegiatan belajar yang seharusnya dilakukan secara tatap muka, seperti biasanya harus dihentikan. Sesuai dengan Surat Edaran (SE) yang dikeluarkan oleh Pemerintahan Indonesia juga Menteri Pendidikan dan Kebudayaan Republik Indonesia. Bahwa proses Belajar mengajar harus dilakukan secara daring/jarak jauh, untuk memutus penyebaran virus lebih banyak lagi.

Menurut Isman (dalam Dewi, 2020) pembelajaran daring adalah pembelajaran jarak jauh yang memanfaatkan teknologi internet untuk melakukan pembelajaran tersebut. Oleh karena itu dalam merancang pembelajaran daring harus dilakukan dengan seksama karena mengingat pembelajaran daring berbeda dengan pembelajaran tatap muka seperti pemilihan media, bahan ajar, dan platform yang digunakan (Farida et al., 2020). 
Namun, walaupun seperti itu banyak sekali pertimbangan diantara guru, siswa, dan orangtua. Kebanyakkan masalah yang dihadapi mereka adalah ketidakpunyaan alat elektronik sendiri bagi siswa, juga orangtua yang kurang memahami tentang teknologi.

Oleh karena itu, peneliti ingin mengeluarkan inovasi baru untuk mendukung pembelajaran daring/jarak jauh untuk mengoptimalkan pembelajaran daring, jika suatu saat akan terjadi kembali masalah semacam ini. Peneliti akan pengembangkan Buku Panduan Belajar Siswa Mandari (KUMALASARI) yang nantinya mampu mendukung pembelajaran siswa disaat belajar di rumah, juga mampu digunakan disaat guru/wali kelas tidak mampu mengajar, buku ini mampu menjadi solusinya.

Buku adalah benda yang banyak digunakan oleh manusia, benda yang akrab dengan manusia yang mampu digunakan untuk media menulis maupun dalam bentuk bacaan. Menurut Kamus Besar Bahasa Indonesia buku adalah lembar kertas yang berjilid, berisi tulisan atau kosong.

Menurut Wagiran (dalam Afandi, 2011) dalam "Hegemoni LKS dan Buku Pelajaran yang Tak Layak" menjelaskan bahwa buku yang dirancang dengan baik dan benar akan menjadi media pembelajaran yang efektif. Menurut Alamsyah (2016) buku merupaka salah satu bahan ajar cetak yang dapat dimanfaatkan untuk mencapai tujuan pembelajaran.

Pendidik dalam hal ini sangat berperan penting untuk membuat sebuah inovasi baru dan menarik, agar siswa mampu belajar mandiri dan tidak harus membutuhkan pendamping. Dalam hal ini pendidik harus mengenal konsep buku pedoman/petunjuk belajar bagi siswa.

Menurut Novita (2020) buku pedoman praktikum adalah buku yang di dalamnya memuat petunjuk tata cara melakukan praktikum mulai dari persiapan, pelaksanaan, dan pelaporan praktikum.

Dari penjelasan tersebut dapat disimpulkan bahwa buku pedoman adalah buku yang berisikan petunjuk dan arahan untuk melakukan sesuatu, juga memberikan informasi dan penunjang pembelajaran supaya siswa mampu melakukan persiapan untuk melakukan suatu kegiatan.

Tujuan pengembangan ini adalah mengembangkan produk berupa Buku Pedoman Belajar Siswa Mandiri (KUMALASARI).

\section{Metode Penelitian}

Penelitian ini bertujuan untuk mengembangkan produk berupa buku pedoman belajar siswa mandiri (kumalasari) untuk siswa kelas V SD. Berdasarkan tujuan penelitian tersebut metode penelitian yang digunakan adalah R \& D (Research and Development). Menurut Sugiyono (2013) R\&D adalah metode penelitian yang digunakan untuk menghasilkan sebuah produk, serta pengujian keefektifan produk tersebut sedangkan Borg dan Gall (dalam Sugiyono, 2013) menjelaskan bahwa Research and Development (R\&D) adalah penelitian yang digunakan untuk 
mengembangkan atau memproduksi suatu produk serta memvalidasi produk tersebut, yang digunakan untuk pendidikan dan pembelajaran.

Adapun tahapan R\&D Borg and Gall, yang memiliki 10 langkah penelitian dan pengembangan, yaitu: (1) Potensi dan Masalah, (2) Pengumpulan Data, (3) Desain Produk, (4) Validasi Desain, (5) Revisi Desain, (6) Uji coba Desain, (7) Revisi Produk, (8) Uji Coba Pemakaian, (9) Revisi Produk, (10) Produksi Masal, (Sugiyono, 2013). Adapun tahapan tersebut disajikan pada gambar 1 .

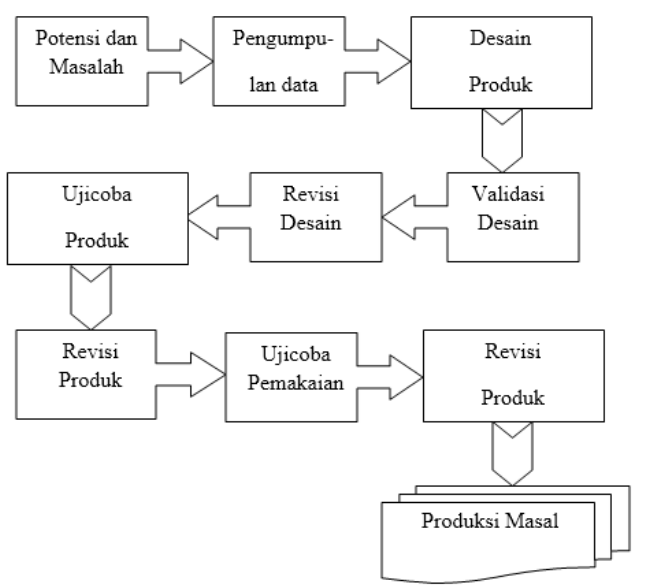

Gambar 1: Tahapan R\&D Borg and Gall

Berdasarkan kondisi saat pelaksanaan penelitian yaitu, bersamaan dengan pandemi covid 19 maka tahapan penelitian yang dilakukan adalah (1) Potensi dan Masalah, (2) Pengumpulan Data, (3) Desain Produk, (4) Validasi Desain, (5) Revisi Desain. Data pada penelitian ini adalah, data kualitatif dan kuantitatif. Data kualitatif adalah, data pelaksanaan proses pengembangan memalui model Borg \& Gall, sedangkan data kuantitatif yaitu, data angket orang tua dan data wawancara guru serta data validasi. Instrumen penelitian yang digunakan adalah, lembar catatan proses pengembangan, lembar angket, lembar wawancara dan lembar validasi. Subjek penelitian adalah siswa kelas $V$ SDN Gesikharjo Palang Kabupaten Tuban.

\section{Hasil dan Pembahasan}

\section{Potensi dan Masalah}

Adanya persebaran Covid 19 yang sangat mengkhawatirkan maka pemerintah memberikan instruksi bahwa, pelaksanaan pembelajaran di era pandemi dilakukan secara daring. Masalah muncul di SDN Gesikharjo I Palang di mana pembelajaran yang seharusnya dilakukan daring tidak berjalan kondusif. Penyebabnya adalah, siswa tidak memiliki smartphone secara individu karena handphone adalah milik orang tua dan dibawa bekerja sehingga siswa melakukan melihat instruksi dari guru setelah sore bahkan malam hari, setelah orang tua pulang dari bekerja. Adapun aplikasi yang digunakan guru adalah whatsapp itupun untuk berkomunikasi dengan siswa dan orang tua terkait tugas yang harus dikerjakan. 
Hal tersebut menjadikan kegiatan sebagai sarana komunikasi antara guru pembelajaran tidak kondusif. orang tua dan siswa tentang tugas yang Berdasarkan hal tersebut maka perlu harus dikerjalan, $85 \%$ orang tua merasa adanya sebuah alternatif solusi untuk petunjuk dalam pembelajaran yang menggatasi masalah yang terjadi. diberikan guru kurang jelas, dan $100 \%$ Berdasarkan masalah yang dihadapi orang tua menginginkan adanya solusi maka potensi untuk mengatasinya untuk mengatasi masalah yang dihadapi. adalah, mengembangkan sebuah buku petunjuk untuk meandu siswa dalam melaksanakan pembelajaran di rumah. Berdasarkan analisis masalah maka dikembangkan Buku Pedoman Balajar mandiri (KUMALASARI) bagi siswa kelas V SD.

\section{Pengumpulan Data}

Pengumpulan data dilakukan untuk mendapatkan data yang faktual dan up to date dari berbagai sumber informasi yang dapat digunakan sebagai bahan untuk perancangan produk yang bertujuan untuk mengatasi masalah yang terjadi. Pada tahap pengumpulan data, yang dilakukan tim peneliti adalah, mengumpulkan data angket orang tua, angket siswa dan wawancara dengan guru terkait pelaksanaan pembelajaran selama era pandemi. Data yang terkumpul dari angket orang tua adalah, $85 \%$ orang tua tidak mendampingi siswa saat belajar di rumah sehingga hanya $25 \%$ yang mendampingi, $100 \%$ orang tua merasa pembelajaran tidak efektif karena Data angket siswa adalah, 85\% siswa merasa jenuh karena pembelajaran hanya diminta mengerjakan tugas evaluasi memalui chat di whatsapp group, $100 \%$ siswa menginginkan kegiatan pembelajaran di rumah dapat dilakukan seperti di kelas, $85 \%$ menginginkan petunjuk yang jelas untuk melaksanakan kegiatan pembelajaran saat era pandemi. Hasil wawancara dengan guru didapatkan bahwa guru hanya bisa menggunakan aplikasi whatsapp dalam memandu siswa untuk belajar, guru merasa pembelajaran kurang efektif karena siswa hanya mengerjakan tugas evaluasi, guru menginginkan adanya solusi untuk mengatasi masalah yang dihadapi.

\section{Desain Produk}

Hasil potensi dan masalah serta pengumpulan data dijadikan acuan untuk membuat desain produk. Pada tahap kegiatan yang dilakukan meliputi, melakukan desain awal produk. Pada bagian ini dijelaskan pada Tabel 1 hanya memalui whatsapp dan itupun 
Tabel 1: Desain Produk Pada Pembelajaran 1

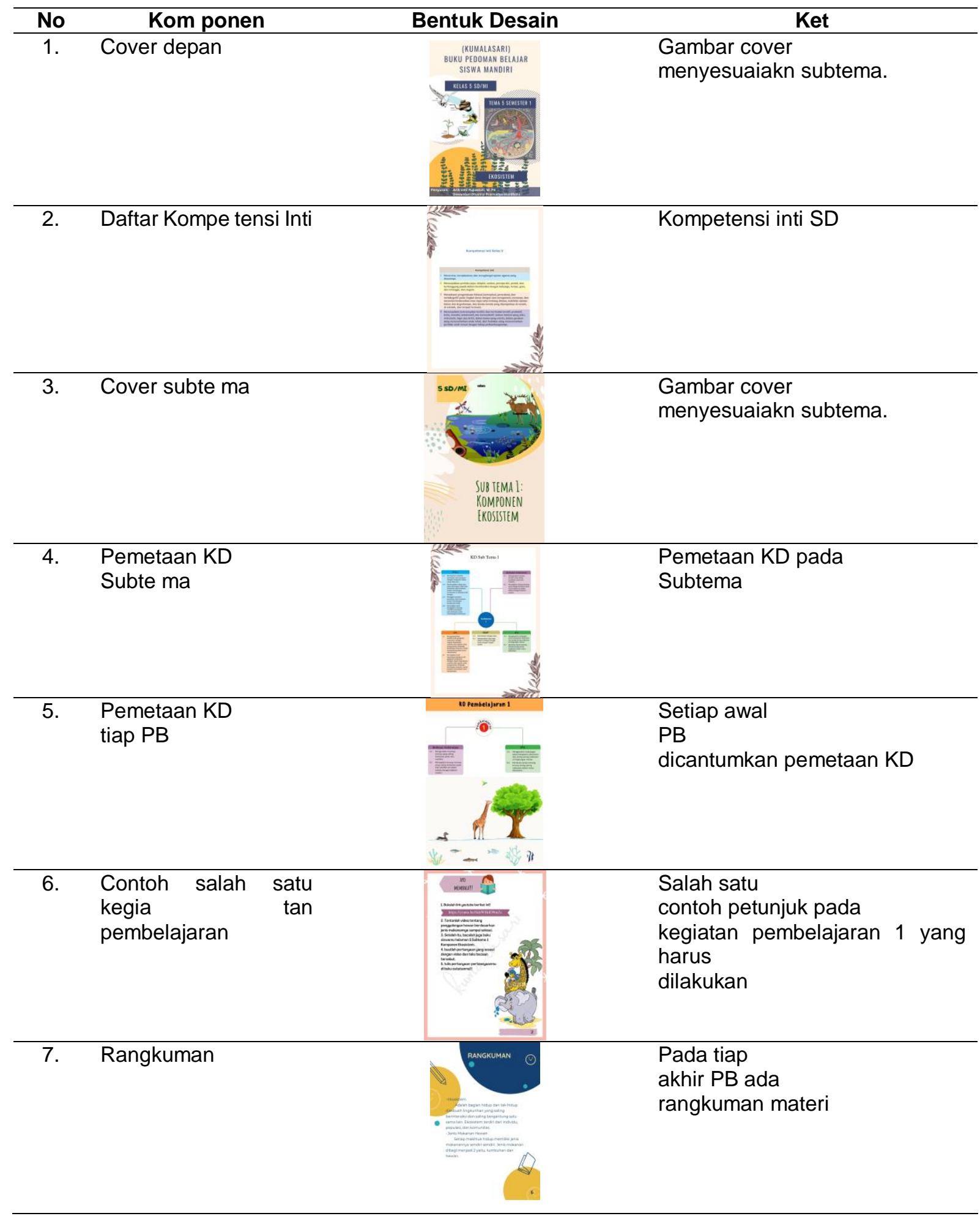

Desain produk yang dilakukan nantinya menjadi acuan untuk dilanjutnya merupakan desain awal yang menjadi acuan pada Pembelajaran 2 sampai 6 . untuk hanya pada Pembelajaran 1 di mana 
Validasi Produk

Hasil rancangan produk yang sudah disusun kemudian dilakukan validasi untuk mengetahui tingkat validitas produk. Adapun kriteria validitas produk
(KUMALASARI) dilihat dari tiga komponen yaitu, isi materi, bahasa, dan desain. Hasil validasi disajikap pada tabel 2,3 , dan 4.

Tabel 2: Hasil validasi ahli materi

\begin{tabular}{|c|c|c|c|}
\hline No & Indikator penilaian & Tahap 1 & Tahap 2 \\
\hline 1. & Kesesuaian gambar, ilustrasi, materi dan tugas & 3 & 5 \\
\hline 2. & Kesesuaian kalimat dengan konsep materi & 2 & 4 \\
\hline 3. & Keruntutan materi & 2 & 5 \\
\hline 4. & Materi, tugas, dan gambar, serta ilustrasi kontektual & 3 & 5 \\
\hline 5. & Materi aktual & 3 & 5 \\
\hline & Skor yang didapatkan & 13 & 24 \\
\hline & Skor maksimal & 25 & 25 \\
\hline & Rata-rata & 2.6 & 4.8 \\
\hline & Persentase & $52 \%$ & $96 \%$ \\
\hline & Kriteria & Cukup & $\begin{array}{c}\text { Sangat } \\
\text { baik }\end{array}$ \\
\hline
\end{tabular}

\section{Tebel 3: Hasil validasi ahli bahasa}

\begin{tabular}{clcc}
\hline No & \multicolumn{1}{c}{ Indikator penilaian } & Tahap 1 & Tahap 2 \\
\hline 1. & Penggunaan kalimat & 2 & 4 \\
\hline 2. & Kesesuaian kalimat dengan kaidah bahasa Indonesia & 2 & 4 \\
\hline 3. & Pemilihan kata/diksi. & 2 & 4 \\
\hline 4. & Penggunaan kalimat petunjuk & 2 & 4 \\
\hline \multicolumn{2}{c}{ Skor yang didapatkan } & $\mathbf{8}$ & $\mathbf{1 6}$ \\
\hline Skor maksimal & $\mathbf{2 0}$ & $\mathbf{2 0}$ \\
\hline Rata-rata & $\mathbf{2}$ & $\mathbf{4}$ \\
\hline Persentase & $\mathbf{2 0 \%}$ & $\mathbf{8 0 \%}$ \\
\hline Kriteria & kurang & baik
\end{tabular}

Tabel 4: Hasil validasi ahli desain

\begin{tabular}{clcc}
\hline No & \multicolumn{1}{c}{ Indikator penilaian } & Tahap 1 & Tahap 2 \\
\hline 1. & Penggunaan huruf & 2 & 4 \\
\hline 2. & Komposisi halaman & 2 & 4 \\
\hline 3. & Penggunaan gambar ilustrasi & 3 & 5 \\
\hline 4. & Pengunaan kertas & 3 & 5 \\
\hline 5 & Kemenarikan cover buku pedoman & 3 & 5 \\
\hline \multicolumn{2}{c}{ Skor yang didapatkan } & $\mathbf{1 3}$ & $\mathbf{2 3}$ \\
\hline Skor maksimal & $\mathbf{2 5}$ & $\mathbf{2 5}$ \\
\hline Rata-rata & $\mathbf{2 . 6}$ & $\mathbf{4 . 6}$ \\
\hline & $\mathbf{5 2 \%}$ & $\mathbf{9 2 \%}$ \\
\hline & Persentase & Cukup & $\begin{array}{c}\text { Sangat } \\
\text { baik }\end{array}$ \\
\hline
\end{tabular}

Berdarakan tabel 2,3,4 hasil validasi sampai 6 , seperti pada gambar di bawah KUMALASARI disajikan pada gambar 2 ini: 


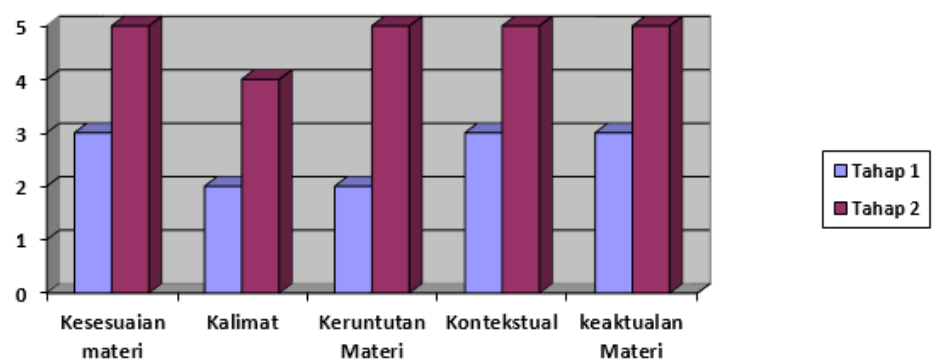

Gambar 2: Hasil validasi ahli materi

Pada tabel 2 dan gambar 1 diketahui materi, tugas, dan gambar, serta ilustrasi validasi yang dilakukan ahli materi pada kontektual, san 5) materi aktual pada lima indikator yaitu, 1) kesesuaian antara tahap satu mendapatkan skor masinggambar ilustrasi materi serta tugas masing, 3, 2, 2, 3, 3 sedangkan pada mendapat, 2) kesesuaian kalimat dengan tahap 2 skor yang didapatkan 5, 4, 5, 5, 5 . konsep materi, 3) keruntutan materi, 4)

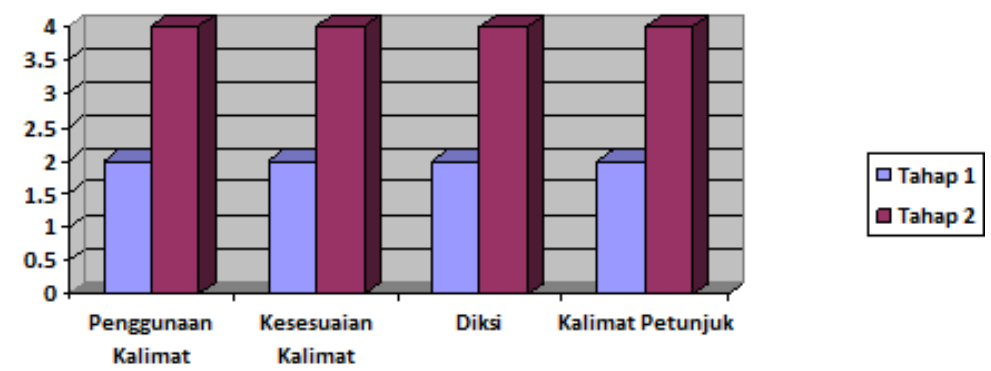

Gambar 3: Hasil validasi ahli bahasa tahap 1 dan 2

Hasil validasi ahli bahasa pada dan 2. Pada indikator 1 sampai 4 tabel 3 dan gambar 2 dideskripsikan mendapatkan skor sama ditahap 1 yaitu 2 bahwa dari lima indikator penilaan dan tahap 2 mendapat skor 4. mengalami peningkatan pada tahap 1

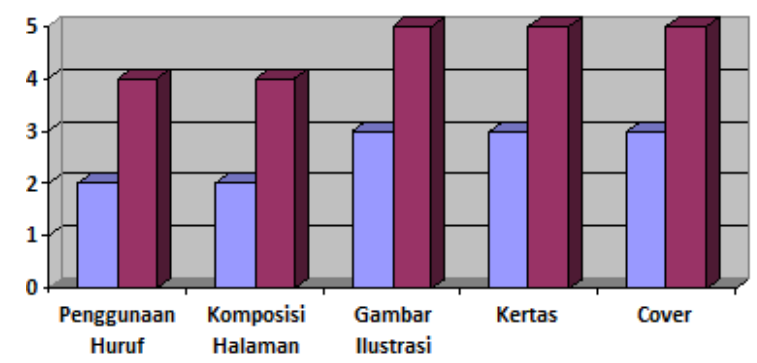

\section{Gambar 4: Hasil validasi ahli desain tahap 1 dan 2}

Sama seperti hasil skor validasi mengalami peningkatan perolehan skor dari ahli materi dan bahasa pada validasi dari tahap 1 dan tahap 2. Pada tabel 4, yang dilakukan oleh ahli desain juga gambar 3 diketahui pada indikator 
penilaian 1 dan 2 ditahap 1 mendapat sampai 5 memperoleh skor 3 ditahap 1 skor 2 dan tahap 2 mendapat skor 4 , dan skor 5 ditahap 2 . begitu juga pada indikator penilaian no 3

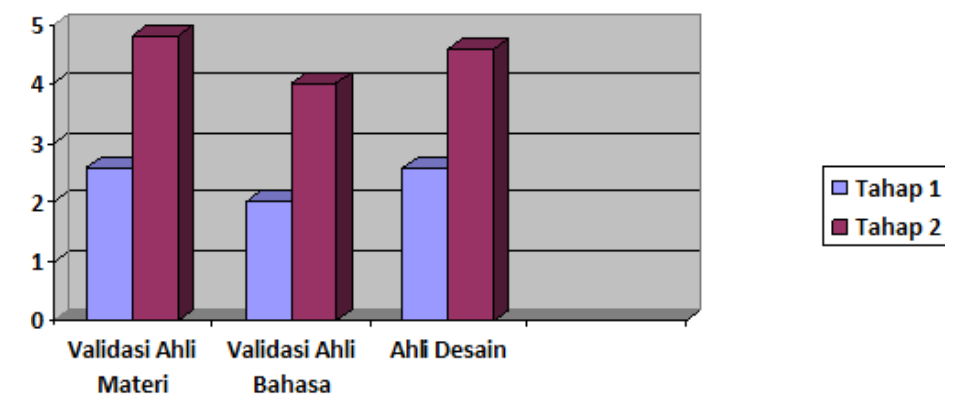

Gambar 5: Rata-rata hasil validasi tahap 1 dan 2

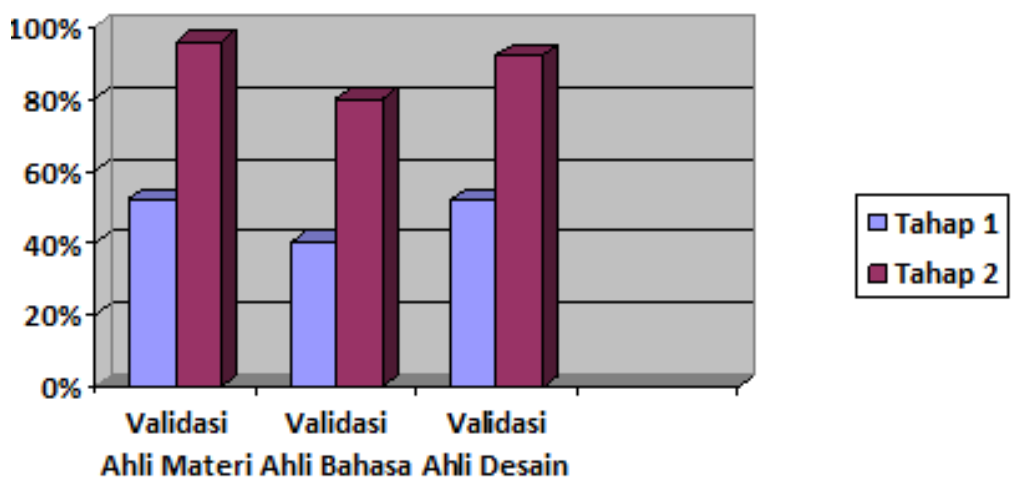

Gambar 6: Persentase hasil Validasi

Validasi yang dilakukan oleh tiga adalah, tahap 1 sebesar $52 \%$ dan tahap ahli, materi, bahasa, dan desain 92\%. Hasil perentase yang didapatkan berdasarkan gambar 4 mendapatkan skor menjadikan kriteria validitas kelayakan rata-rata pada tahap 1 yaitu 2.6, 2, dan pada produk mencapai $89.33 \%$ dengan 2.6 sedangkan pada tahap 2 rata-rata kriteria sangat valid sehingga produk yang didapatkan yaitu, 4.8, 4, dan 4.6. layak digunakan.

Pada gambar 5 Hasil persentase Revisi Desain pada ahli materi tahap 1 sebesar $52 \%$ dan tahap 1 meningkat menjasi 96\%. Hasil persentase ahli bahasa adalah, tahap 1 $20 \%$ dan tahap $280 \%$. Persentase hasil validasi yang dilakukan ahli desain

Revisi desain dilakukan berdasarkan hail validasi dari ahli materi, bahasa dan desain. Adapun revisi dari para ahli disajikan pada tabel 5-7 berikut. 
Tabel 5: Revisi Ahli Materi

\begin{tabular}{|c|c|c|c|}
\hline No & Indikator penilaian & Revisi Tahap 1 & Revisi Tahap 2 \\
\hline 1. & $\begin{array}{l}\text { Kesesuaian gambar, ilustrasi, } \\
\text { materi dan tugas. }\end{array}$ & $\begin{array}{l}\text { Materi dan tugas } \\
\text { hendaknya } \\
\text { mengarah ke HOTS. }\end{array}$ & Sudah direvisi \\
\hline .2 & $\begin{array}{l}\text { Kesesuaian kalimat dengan } \\
\text { konsep materi. }\end{array}$ & $\begin{array}{l}\text { Kalimat yang } \\
\text { digunakan } \\
\text { hendaknya singkat } \\
\text { padat, dan jelas. }\end{array}$ & Sudah direvisi. \\
\hline 3. & Keruntutan materi. & $\begin{array}{l}\text { Alangkah baiknya } \\
\text { materi disesuaikan } \\
\text { dengan } \mathrm{Pb} \text {. }\end{array}$ & Sudah direvisi. \\
\hline 4. & $\begin{array}{l}\text { Materi, tugas, dan gambar, } \\
\text { serta ilustrasi kontektual. }\end{array}$ & $\begin{array}{l}\text { Mohon dicek kembali } \\
\text { apakah materi yang } \\
\text { disajikan sudah } \\
\text { kontekstual. }\end{array}$ & Sudah direvisi. \\
\hline & Materi aktual. & $\begin{array}{l}\text { Materi hendaknya } \\
\text { aktual mengikuti } \\
\text { perkembangan dan } \\
\text { permasalahan yang } \\
\text { sedang trending } \\
\text { topik. }\end{array}$ & Sudah direvisi. \\
\hline
\end{tabular}

Tabel 6: Revisi Ahli Bahasa

\begin{tabular}{cclc}
\hline No & \multicolumn{1}{c}{ Indikator penilaian } & \multicolumn{1}{c}{ Tahap 1 } & \multicolumn{1}{c}{ Tahap 2 } \\
\hline 1. & Penggunaan kalimat & $\begin{array}{l}\text { Hendaknya kalimat } \\
\text { yang digunakan } \\
\text { komunikatif. }\end{array}$ & Sudah direvisi. \\
\hline 2. & $\begin{array}{l}\text { Kesesuaian kalimat dengan } \\
\text { kaidah bahasa Indonesia }\end{array}$ & $\begin{array}{l}\text { Mohon dilihat } \\
\text { penggunaan tanda } \\
\text { baca. }\end{array}$ & Sudah direvisi. \\
\hline 3. & Pemilihan kata/diksi. & $\begin{array}{l}\text { Kata yang dipilih } \\
\text { disesuaikan dengan } \\
\text { konteks materi pada } \\
\text { tiap PB. }\end{array}$ & Sudah direvisi. \\
\hline 4. & Penggunaan kalimat petunjuk. & $\begin{array}{l}\text { Penggunaan kalimat } \\
\text { petunjuk lebih baik } \\
\text { menggunakan }\end{array}$ & Sudah direvisi. \\
& & $\begin{array}{l}\text { penomoran sehingga } \\
\text { rinci. }\end{array}$ & \\
\hline
\end{tabular}




\section{Tabel 7: Revisi Ahli Desain}

\begin{tabular}{lll}
\hline No Kom ponen revisi & Bentuk awal Desain \\
1. Pada peta konsep \\
pemetaan KD PB 1-6 \\
kurang jelas, perbaikan \\
capture dengan kualitas \\
yang lebih tinggi, agar \\
peta konsep terlihat \\
jelas.
\end{tabular}

\section{Kesimpulan}

Berdasarkan hasil validasi yang dilakukan ahli materi, ahli bahasa, dan ahli desain produk KUMALASARI sangat valid dan layak digunakan. Saran untuk pengembangan dapat dilanjutkan untuk subtema lain dan dapat juga dikembangkan produk serupa dalam bentuk digital. 


\section{Daftar Pustaka}

Afandi, M. I. (2011). Pengembangan Buku Panduan Pengasuhan Untuk mengembangkan Potensi Membaca anak Usia Prasekolah. Universitas Negeri Semarang.

https://scholar.google.com/scholar?cluster=10826048410576994510\&hl=id\&as_ $\mathrm{sdt}=0,5$

Alamsyah, A. (2016). Karakteristik Buku Teks Akidah Akhlak Kelas XI Madrasah Aliyah 'Aisyiyah Palembang dan Madrasah Aliyah Al-Khoiriyah Desa Timbul Jaya Kec. Muara Sugihan Kab. Banyuasin. [Skripsil]. UIN Raden Fatah Palembang. http://repository.radenfatah.ac.id/id/eprint/1089\%0A

Dewi, W. A. F. (2020). Dampak Covid-19 terhadap Implementasi Pembelajaran Daring di Sekolah Dasar. Edukatif: Jurnal IImu Pendidikan, 2(1), 55-61. https://doi.org/https://doi.org/10.31004/edukatif.v2i1.89

Farida, I., Rahmawati, R., Aisyah, R., \& Helsy, I. (2020). Pembelajaran Kimia Sistem Daring di Masa Pandemi Covid-19 bagi Generasi Z. KTI Massa WHF Pandemi Covid-19. http://digilib.uinsgd.ac.id/30638/1/KTI -Ida Farida\%2Cdkk- P Kimia.pdf

Hermawan, D., Rahmawanti, N., \& Dony, N. (2019). Pengembangan Buku Pengayaan Kimia sebagai Alternatif Sumber Belajar Mandiri pada Pembelajaran Kimia tentang Larutan Elektrolit dan Nonelektrolit. Universitas Islam Kalimantan. http://repository.uniska-bjm.ac.id/id/eprint/583

Mehta, P., McAuley, D. F., Brown, M., Sanchez, E., Tattersall, R. S., \& Manson, J. J. (2020). COVID-19: Consider Cytokine Storm Syndromes And Immunosuppression. The Lancet, 395(10229), 1033-1034. https://doi.org/https://doi.org/10.1016/S0140-6736(20)30628-0

Novita, E. (2020). Pengembangan Buku Pedoman Praktikum Berbasis Keterampilan Proses Dasar Sains Kelas IV Sekolah Dasar. Journal Evaluation in Education (JEE), 1(1), 34-41. https://doi.org/https://doi.org/10.37251/jee.v1i1.38

Rahayu, N. R. (2019). Hubungan Kemandirian dengan Hasil Belajar Peserta Didik (Penelitian Kuantitatif Korelasional Pada Peserta Didik Kelas V SD Negri Se-Desa Rancamanyar Kecamatan Baleendah Kabupaten Bandung). FKIP UNPAS. http://repository.unpas.ac.id/id/eprint/45495

Sugiyono, D. (2013). Metode Penelitian Pendidikan Pendekatan Kuantitatif, Kualitatif dan $R \& D$. Alfabeta. https://digilib.unigres.ac.id/index.php?p=show_detail\&id=43

Xu, Z., Shi, L., Wang, Y., Zhang, J., Huang, L., Zhang, C., Liu, S., Zhao, P., Liu, H., \& Zhu, L. (2020). Pathological Findings of COVID-19 Associated with Acute Respiratory Distress Syndrome. The Lancet Respiratory Medicine, 8(4), 420-422. https://doi.org/https://doi.org/10.1016/S2213-2600(20)30076-X 